\title{
Teaching
Methods
}

\section{Is an Instructional Video Better than a Face-to-face Demo to Teach T-budding in an Intro Plant Propagation Course?}

\section{Nadilia Gómez ${ }^{1}$}

ADDITIONAL INDEX WORDs. educational technology, Hibiscus, grafting, videobased teaching

\begin{abstract}
Summary. Teaching grafting techniques like T-budding is challenging because learners must pay close attention to detail, observing closeups of plant structures and following specific sequences, and such attention to detail is difficult to achieve in large enrollment classes. The objective of this study was to compare the effectiveness of an instructional video vs. traditional face-to-face demonstrations to teach T-budding. A 10-minute instructional video demonstrating the steps necessary for T-budding was developed in 2001. For three consecutive years $(2001,2002$, and 2003) the two methods were compared by having students see a video or receive a face-to-face demonstration, asking them to graft three buds to a root-
\end{abstract}

\footnotetext{
${ }^{1}$ Department of Horticultural Science, University of Minnesota, St. Paul, MN 55108. E-mail address: gome0046@umn.edu

Acknowledgments: Thanks to E. Hoover, W. Peters, K. Vidmar, K. Zambreno, D. Zlesak, R. Meissner, S. Wetzel, J. Ross, K. Young, and to the reviewers. This research has been supported in whole or in part by the Minnesota Agricultural Experiment Station (Publication No. 041210125).
}

stock and then complete a survey. Ninety students were taught T-budding with the aid of the video, and 80 students received traditional, face-toface demos. In the survey, students were asked to evaluate the clarity of the $\mathrm{T}$-budding instructions, rate the amount of help they needed from the instructor, assess the level of difficulty of T-budding, and answer two questions that tested their conceptual knowledge of T-budding. There was no difference between the two groups in the amount of time it took for students to complete the assignment and in terms of the perceived level of difficulty of the assignment. Students reported that the clarity of the face-to-face demonstrations was better than that of the video presentation, but students who saw the video obtained higher scores in the quiz than those who received a face-to-face demonstration.

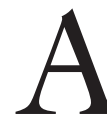
t least 67 higher education institutions across Canada and the U.S. offer horticultural science majors (Peterson's, 2000). Students in horticulture generally are required to take an introductory plant propagation course where they learn grafting techniques, such as T-budding. Although live demonstrations are often impractical and advances in technology permit the implementation of innovative teaching strategies, most plant propagation instructors still use the traditional, face-to-face method to teach T-budding. One alternative teaching strategy involves the use of an instructional video (Quigley, 1988). A teaching strategy involving videos can be highly motivational compared to more traditional methods (Lin and Fox, 1999).

The main objective of this study was to evaluate the advantages of an instructional video to teach T-budding. The specific questions are whether the video, relative to a face-to-face demonstration: 1) allows students to perform grafts faster; 2) improves the clarity of the presentation; 3 ) allows students to accomplish the assignment with minimal assistance from the instructor; 4) presents the technique as an easyto-accomplish task; and 5) improves students' test scores on a quiz that tests concepts related to T-budding.

\section{Materials and methods}

A 10-min instructional video titled T-budding: Plant Propagation Instructional Video was produced by a University of Minnesota staff member and a professional videographer (Wetzelco Productions, Milwaukee, Wis.). Depending on the quality and complexity of instructional videos, production costs can vary significantly. Price estimates for professional instructional videos include a videographer's fee (approximately $\$ 100 / \mathrm{h}$ ) that covers storyboarding, shooting, and editing. Graphics and script development are often considered additional expenses (G. Erickson, personal communication).

The script and footage design were developed, taking into consideration video production and evaluation guidelines (Beaudin and Quick, 1996; Ludlow and Duff, 1997). The script, describing materials needed and steps required for $\mathrm{T}$-budding, was based on the Hort 1001 Plant Propagation Lab Manual (Calkins and Hoover, 2000). The video also demonstrates how to distinguish a successful graft by the appearance of the scion's petiole.

Five instructors and their lab sections participated in the evaluation, with two lab sections in 2001 , one in 2002, and two more in 2003. Students were given a lab manual with T-budding instructions at least 1 week before the lab, and were asked to read the manual before class. During the lab experience, the instructors showed the video (test group) or demonstrated the procedure themselves (face-toface, control group). For the control group, the instructors were allowed to demonstrate the technique to the entire group at once or to smaller groups of at least five students per group.

Ninety students saw the video, and 80 received face-to-face demos. Students were asked to T-bud three scions to a single rootstock from a variety of compatible cultivars of tropical hibiscus (Hibiscus sinensis). After 
Fig. 1. Survey questions completed by students in Hort 1001 Plant Propagation course $(\mathrm{n}=170)$ after receiving $T$-budding instruction via a video-based demonstration $(n=90)$ or a live demonstration $(n=80)$. In question 1 , students recorded the time it took to graft three buds. The knowledge and experience students had prior to the demonstrations is assessed in questions 2 and 3. Differences between the video and the instructors' live demonstration in terms of the clarity of the explanation, the amount of assistance students required from the instructors, and the perceived level of difficulty of the assignment are also assessed in the survey. Questions 8 and 9 test the student's conceptual knowledge on two aspects of $\mathrm{T}$-budding (the correct answers are in bold print).

\section{T-budding Survey}

\section{Please complete this survey after grafting three scions to a rootstock.}

1. How long (minutes) did it take you to complete three grafts?

2. Have you T-budded before?

$$
\square \text { yes } \quad \square \text { no }
$$

3. Did you read the lab manual before coming to lab?

$$
\square \text { yes } \quad \square \text { no }
$$

4. If you received a face-to-face demo, rate the clarity of the presentation.

$$
\square \text { very clear } \square \text { clear } \square \text { unclear }
$$

5. If you saw the T-budding video, rate the clarity of the video presentation.

$$
\square \text { very clear } \square \text { clear } \square \text { unclear }
$$

6. How much help did you need from the instructor while performing the T-budding?

$\begin{array}{lll}\square \text { lots of help } & \square \text { some help } \\ \text { (more than twice) } & \text { (1-2 times) help }\end{array}$

7. How would you rate the level of difficulty of T-budding?

$$
\square \text { very easy } \square \text { easy } \square \text { average } \square \text { difficul }
$$

8. How do you know your grafting was successful?

a. You sneak a peak under the budding strip.

b. The petiole turns yellow and falls.

c. The petiole dries and remains attached.

9. Why is it called T-budding?
a. The hibiscus variety is 'Tamara'.
b. The bud is cut in the shape of a "T."
c. The cut on the stem is in the shape of a "T."

T-budding, students were asked to complete a survey (Fig. 1).

All statistical tests were done at a 95\% significance level $(\alpha=0.05)$. Groups were compared for mean time to task completion using a one-way analysis of variance. All other data were tested for independence using Pearson chi-square statistic $\left(\chi^{2}\right)$ which is appropriate for contingency tables where more than $20 \%$ of the cells have expected counts less than five (Sall et al., 2001).

\section{Results and discussion}

Students who had previous Tbudding experience or had not read the manual before class were equally distributed between groups (Table 1). Therefore, no differences are due to students' T-budding experience before lab.

The time it took for students to complete the assignment did not differ significantly between groups. Students who saw the video took an average of $19 \mathrm{~min}$, while students who received the face-to-face demonstration took $21 \mathrm{~min}(\mathrm{sE}=1.2, P=0.2401)$. To allow more time for students to practice the technique, the instructional video could be shortened and used exclusively to show close-ups and time-lapse progressions.

The clarity of the instructions depended on the type of demonstration received, with more students rating the face-to-face demonstration as very clear. During a face-to-face demonstration, students often ask the instructor to clarify procedures as they occur. It is possible that confusion stemmed from being unable to ask questions as the process is being demonstrated. However, instructional videos can be utilized in a manner that addresses this issue; instructors can pause the video when necessary, controlling the rate of flow of information and allowing time for students to ask questions (Ludlow and Duff 1997).

Despite a reduction in the clarity of the video demo, students were able to graft without instructor's assistance regardless of the type of demonstration received. There was no significant difference in the perceived level of the procedure's difficulty between students who saw the video vs. the ones that received a face-to-face demonstration. These results suggest that clarity of video instruction did not adversely affect students' ability to complete the assignment independently and their perceptions of the difficulty associated with the assignment.

In contrast to other studies that have found no difference in grades between students who receive video instructions or traditional training (Lewis, 1995; Lyness, 1985), better grades were obtained by students who saw the T-budding video than by those who received a face-to-face demo. Students who saw the video were more likely to answer question 8 correctly because the demonstration of a senescing petiole depicted in the video involves a time lapse that is impractical in live demos. Even though the answer was in the manual, visual representation provided by the video may have helped students remember the concept better.

In conclusion, instructional videos are effective teaching tools. In some aspects they are better than traditional techniques. In other cases, they can be improved to accommodate student learning needs. Instructors can use videos to show close-ups to several students simultaneously, precisely replicate a demonstration numerous times (Bosco, 1984), incorporate demonstrations that would be expensive or time-consuming (Hardwood and McMahon, 1997; Kearney, 2002), or make instructions available via a class web page. Instructional videos provide the versatility that face-to-face demonstrations lack. Their use enhances the students' learning experience.

\section{Literature cited}

Beaudin, B.P. and D. Quick. 1996. Instructional video evaluation instrument. J. Ext. 34(3). 15 June 2004. <http://www.joe. org/joe/1996june/al.htmls.

Bosco, J. 1984. Interactive video: Educational tool or toy? Educ. Technol. 24(3):13-19. 
Table 1. Survey results from students who received T-budding instruction via video technology $(n=90)$ or live-demonstration $(n=80)$. Responses (counts) were tested for independence with a Pearson chi-square $\left(\chi^{2}\right)$ statistic. Except for the response categories related to the preparation before lab, $20 \%$ of the cells had expected counts less than five in all contingency tables. Tests for independence exclude responses where no answers were provided.

\begin{tabular}{|c|c|c|c|}
\hline Survey response & $\begin{array}{l}\text { Video demo } \\
(\% \text { responses })\end{array}$ & $\begin{array}{c}\text { Face-to-face demo } \\
(\% \text { responses })\end{array}$ & $\chi^{2}$ \\
\hline \multicolumn{4}{|l|}{ Preparation before lab: } \\
\hline Never T-budded before & 93.3 & 97.5 & \\
\hline Had T-budded before & 6.7 & 2.5 & $1.64^{\mathrm{Ns}}$ \\
\hline Read manual & 71.1 & 66.7 & \\
\hline Did not read manual & 26.7 & 20.0 & \\
\hline No answer & 2.2 & 2.2 & $0.39^{\mathrm{Ns}}$ \\
\hline \multicolumn{4}{|l|}{ Clarity of demonstration: } \\
\hline Very clear & 48.9 & 66.3 & \\
\hline Clear & 47.8 & 28.8 & \\
\hline Unclear & 1.1 & 0.0 & \\
\hline No answer & 2.2 & 5.0 & $7.06^{*}$ \\
\hline \multicolumn{4}{|l|}{ Assistance required: } \\
\hline Lots of help & 2.2 & 5.6 & \\
\hline Some help & 41.1 & 35.6 & \\
\hline No help & 54.4 & 46.7 & \\
\hline No answer & 2.2 & 1.3 & $1.71^{\mathrm{Ns}}$ \\
\hline \multicolumn{4}{|l|}{ Level of difficulty: } \\
\hline Very easy & 5.6 & 5.0 & \\
\hline Easy & 23.3 & 23.8 & \\
\hline Average & 42.2 & 46.3 & \\
\hline Difficult & 27.8 & 25.0 & \\
\hline Very difficult & 1.1 & & $1.20^{\mathrm{Ns}}$ \\
\hline \multicolumn{4}{|l|}{ Correct answers in quiz: } \\
\hline 2 & 90.0 & 81.3 & \\
\hline 1 & 8.9 & 8.8 & \\
\hline 0 & 1.1 & & $6.70^{*}$ \\
\hline
\end{tabular}

Ns, *Nonsignificant or significant at $P \leq 0.05$, respectively.

Calkins, J. and E. Hoover. 2000. Hort 1001 Plant propagation laboratory manual. Dept. of Hort. Sci., Univ. of Minnesota, St. Paul.

Hardwood, W. and M. McMahon. 1997. Effects of integrated video media on student achievement and attitudes in high school chemistry. J. Res. Sci. Teaching 34(6):617-631.

Kearney, M. 2002. Using digital video to enhance authentic technology-mediated learning in science classrooms. Australian Computers in Educ. Conf. Proc. 17 June 2004. <http://www.pa.ash.org.au/ acec2002/uploads/documents/store/ conferences/conf_7_147_kearney.pdf>.

Lewis, R.A. 1995. Video introductions to laboratories: Students positive, grades unchanged. Amer. J. Physics 63(5):468.

Lin, L.-Y. and T. Fox. 1999. A study of motivational effects and related student perceptions of skills improvement attained through the use of variously captioned authentic video materials. U.S. Dept. Educ.
ERIC Document Reproduction Serv. No. ED467254.

Ludlow, B.L. and M.C. Duff. 1997. Creating and using video segments for rural teacher education. U.S. Dept. Educ. ERIC Document Reproduction Serv. No. ED406106

Lyness, A.L. 1985. Effectiveness of interactive video to teach CPR theory and skills. U.S. Dept. Educ. ERIC Document Reproduction Serv. No. ED256324

Peterson's. 2000. Peterson's guide to four-year colleges. 30th ed. Thompson Peterson's, Lawrenceville, N.J.

Quigley, B. 1988. Using video to enhance instruction. U.S. Dept. Educ. ERIC Document Reproduction Serv. No. ED294573

Sall, J., A. Lehman, and L. Creighton, L. 2001. JMP start statistics: A guide to statistics and data analysis using JMP and JMP IN software. 2nd ed. Duxbury, Pacific Grove, Calif. 